\title{
Further Investigation of Synaptic Vesicle Protein 2A (SV2A) Ligands Designed for Positron Emission Tomography and Single-Photon Emission Computed Tomography Imaging: Synthesis and Structure-Activity Relationship of Substituted Pyridinylmethyl-4- (3,5-difluorophenyl)pyrrolidin-2-ones
}

\author{
Richard Pracitto, Kyle C. Wilcox, Marcel Lindemann, Jie Tong, Chao Zheng, Songye Li,* \\ Sjoerd J. Finnema, Yiyun Huang, and Zhengxin Cai*
}

Cite This: ACS Omega 2021, 6, 27676-27683

Read Online

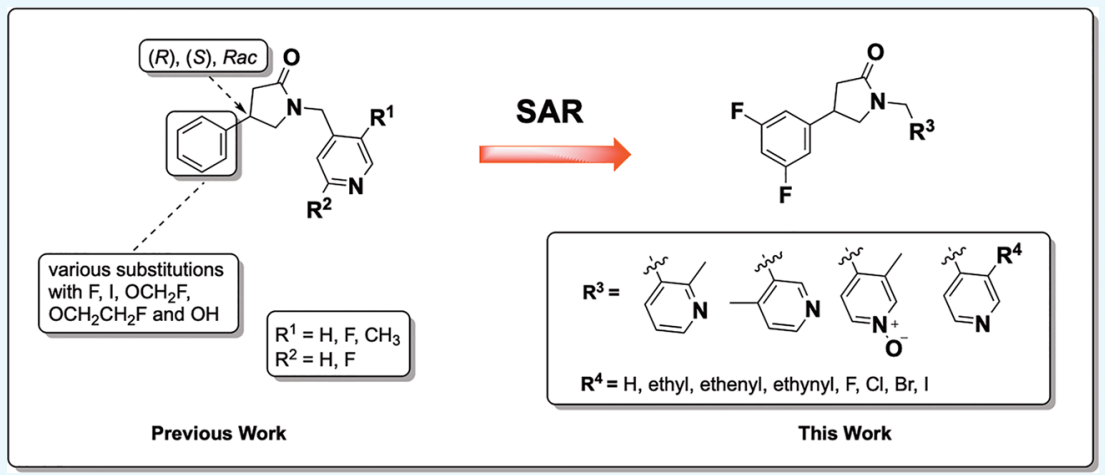

ABSTRACT: A series of synaptic vesicle protein 2A (SV2A) ligands were synthesized to explore the structure-activity relationship and to help further investigate a hydrogen bonding pharmacophore hypothesis. Racemic SynVesT-1 was used as a lead compound to explore the replacement of the 3-methyl group on the pyridinyl moiety with halogens and hydrocarbons. Pyridinyl isomers of racemic SynVesT-1 were also investigated. Highly potent analogs were discovered including a 3-iodo pyridinyl ligand amenable to investigation as a PET or SPECT imaging agent.

\section{INTRODUCTION}

Synapse abnormalities are associated with many neuropsychiatric disorders including schizophrenia and Alzheimer's disease amongst others. ${ }^{1,2}$ Synaptic vesicles (SVs) are small, electronlucent vesicles that are produced and clustered at presynaptic terminals. They are responsible for the storage and release of neurotransmitters and are regenerated pending calciumtriggered exocytosis. SV2 proteins are 12-transmembrane glycoproteins present on the synaptic vesicles of neural cells and part of the large and broadly distributed major facilitator superfamily (MFS). SV2 consists of three isoforms: SV2A, SV2B, and SV2C. ${ }^{3}$ Only SV2A is ubiquitously expressed in essentially all presynaptic vesicles. This favors its use as a biomarker for synaptic density among other expressed proteins at the presynaptic proteome and synaptic vesicles. ${ }^{1}$ The antiepileptics levetiracetam and brivaracetam target SV2A, and levetiracetam has been used as the lead structure in the rational design of the first series of potent SV2A ligands, UCB-A, UCB$\mathrm{H}$, and UCB-J, as candidates for radioligand development for positron emission tomography (PET). ${ }^{3}$
The potent and selective fluoro-substituted 4-phenyl-2pyrrolidinone derivatives (Figure 1) have proven to be important in the area of SV2A PET imaging as synaptic density probes, with $\left[{ }^{11} \mathrm{C}\right] \mathrm{UCB}-\mathrm{J}$ being the most advanced in this series and applied in clinical neuroimaging studies of epilepsy, ${ }^{4} \mathrm{AD},{ }^{5}$ $\mathrm{PD},{ }^{6}$ depression, ${ }^{7}$ and schizophrenia. ${ }^{8,9}$ However, as this class of compounds evolves, some deficiencies have emerged in human trials. For example, $\left[{ }^{11} \mathrm{C}\right] \mathrm{UCB}-\mathrm{A}$ has slow binding kinetics and $\left[{ }^{18} \mathrm{~F}\right] \mathrm{UCB}-\mathrm{H}$ has a relatively low specific binding signal. ${ }^{10-12}$ Therefore, these PET tracers have significant limitations for imaging and quantifying SV2A in human brain. Ongoing evaluation of mono- and di-fluorinated analogs of UCB-J then

Received: May 8, 2021

Accepted: September 22, 2021

Published: October 8, 2021

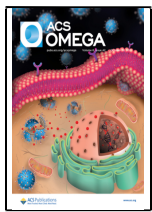


<smiles>Cn1cncc1CN1CC(c2cc(F)cc(F)c2)CC1=O</smiles>

$\left[{ }^{11} \mathrm{C}\right] \cup C B-A(1)$

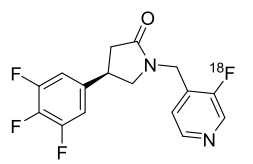

$\left[{ }^{18}\right.$ F]UCB-H (4)

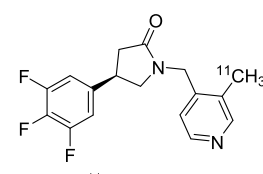

$\left[{ }^{11}\right.$ C]UCB-J (2)

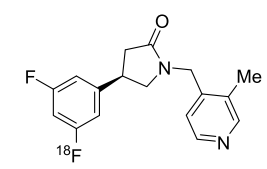

$\left[{ }^{18} \mathrm{~F}\right]$ SynVesT-1 (5)

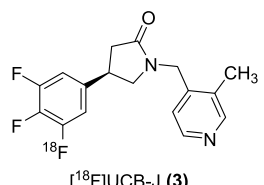

$\left[{ }^{18} \mathrm{~F}\right]$ UCB-J (3)

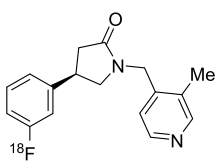

$\left[{ }^{18} \mathrm{~F}\right]$ SynVesT-2 (6)
Figure 1. Current SV2A PET imaging probes in this series.

led to the discovery of the novel ${ }^{18} \mathrm{~F}$-labeled SV2A PET tracers $\left[{ }^{18} \mathrm{~F}\right]$ SynVesT-1 (previously known as $\left[{ }^{18} \mathrm{~F}\right] \mathrm{SDM}-8$ or $\left.\left[{ }^{18} \mathrm{~F}\right] \mathrm{MNI}-1126\right)$ and $\left[{ }^{18} \mathrm{~F}\right]$ SynVesT-2 (also known as $\left.\left[{ }^{18} \mathrm{~F}\right] \mathrm{SDM}-2\right)$ (Figure 1 ), which are currently under first-inhuman investigation. ${ }^{13,14}$

Early efforts toward the discovery of SV2A ligands ultimately lead to the PET tracers shown in Figure 1 including those of Kenda et al. ${ }^{15}$ and Mercier et al. ${ }^{3}$ In the absence of available structural information on SV2A, ligand-based drug design, further supported by discovery medicinal chemistry efforts, has been used by Mercier et al. ${ }^{3}$ to further define a plausible SV2A pharmacophore. This work led to the hypothesis of a pharmacophore with two hydrogen bond acceptors, one represented by the carbonyl of the pyrrolidinone and the other by the nitrogen of its heterocycle, in particular, imidazole, pyrazole, or pyridine. This produced a series of compounds with dramatically increased SV2A binding affinities.

More recently and specifically aimed at developing fluorine18-labeled SV2A PET imaging agents, we and others conducted studies to investigate whether structural analogs of UCB-J had suitable binding affinities. ${ }^{16}$ These studies focused primarily on the variation of the phenyl substituents of the 4-phenylpyrrolidin-2-one portion of the molecule (Figure 2). Analog

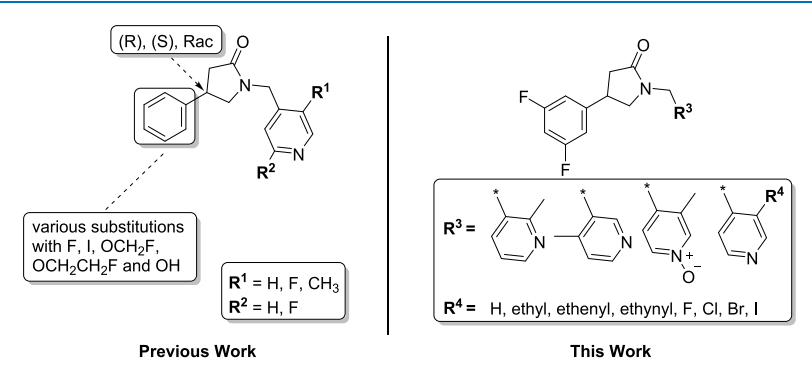

Figure 2. Comparison of this work with previous SAR studies.

screening identified racemic SynVesT-1 (18, 5.1 nM ${ }^{16}$ (4.9 nM in our assays)) as having comparable binding affinities with racemic UCB-J. $\left[{ }^{18} \mathrm{~F}\right]$ SynVesT-1 (5) has demonstrated in vivo uptake and accumulation in the human brain with favorable kinetics. ${ }^{13}$ In addition, studies revealed sensitivity of SV2A binding to modifications at the 1-(pyridin-4-ylmethyl) portion of other 4-phenylpyrrolidin-2-one variants, i.e., UCB-H and SDM-1. ${ }^{16}$ These outcomes presented an opportunity for further SAR studies at the pyridynyl portion of the SynVesT-1 molecule.

With this background in mind, we set out to explore potential changes in binding affinity $\left(K_{\mathrm{i}}\right)$ by modifying the pyridinyl moiety of racemic SynVesT-1 (18). We synthesized a series of compounds according to the following: (1) replacement of the pyridinyl 3-methyl group with halogens or hydrocarbons and (2) changes in the location of nitrogen on the pyridinyl moiety. We also oxidized the pyridinyl nitrogen of racemic SynVesT-1 (Figure 2). The results of this SAR study may provide further insights into the abovementioned pharmacophore hypothesis.

\section{RESULTS AND DISCUSSION}

Analogs were prepared using previously reported methods as shown in Scheme 1. ${ }^{13}$ Starting from commercially available 3,5-

Scheme 1. Primary Synthetic Route to Compounds in This SAR Series

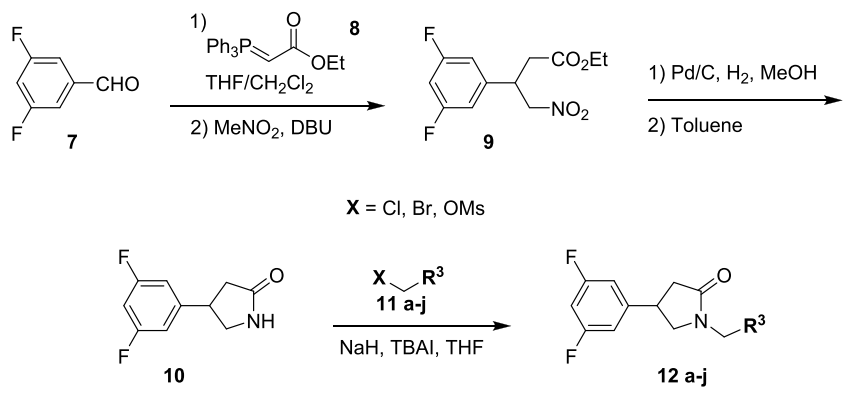

fluorobenzaldehyde (7), the Wittig reaction with (carbethoxymethylene)triphenylphosphorane (8) followed by treatment with nitromethane under basic conditions led to compound 9 in $83 \%$ yield, which was reduced and cyclized to yield pyrrolidinone 10 in $34 \%$ yield. $N$-Alkylation of 10 with various 2- or 3-substituted pyridin-4-ylmethyl halogens or mesylates $(1 \mathbf{1} \mathbf{a}-\mathbf{j})$ generated the compounds represented by $12 \mathbf{a}-\mathbf{j}$ in $5-80 \%$ yield.

The in vitro binding affinity of these compounds was then tested through competition binding assays with $\left[{ }^{3} \mathrm{H}\right] \mathrm{UCB}-\mathrm{J}$ in human brain tissue homogenates (Table 1; Figure SI-14).

Structure-activity relationships among the compounds evaluated in this study are discussed below.

2.1. Position and Oxidation of the Pyridinyl Nitrogen. In general, changing the 3-methyl-pyridinyl group of racemic SynVesT-1 (18, $4.9 \mathrm{nM})$ to a 2-methyl- or 4-methyl-pyridinyl group shows a reduction in affinity, with the 2-methyl isomer (12i, $29.9 \mathrm{nM})$ having higher affinity than the 4-methyl isomer (12j, $291 \mathrm{nM})$. These results support a previously reported model consistent with the pyridine nitrogen acting as a hydrogen bond acceptor. ${ }^{3}$ Studies suggest that the hydrogen bond accepting ability of each pyridynyl nitrogen (2-, 3-, or 4methylpyridinyl) when compared to each other should not be dramatically different. ${ }^{17}$ Therefore, although $\pi$ interactions may also have influence, the notable differences in potency across these methyl-pyridinyl isomers points to the importance of the nitrogen location as a hydrogen bond acceptor when interacting with SV2A.

The pyridinyl $\mathrm{N}$-oxide was the major radiometabolite for pyridinyl-derived SV2A radioligands $\left(2^{9}\right.$ and $\left.4^{18}\right)$, and we found that the oxidation of the pyridinyl nitrogen shows virtually a complete loss of affinity $(\mathbf{1 2 k}, 2.8 \mu \mathrm{M})$. Although more experimental data are necessary to establish a broader understanding of the effect of pyridine- $N$-oxides across this particular series, it has been experimentally determined previously $^{17,19}$ that in general, pyridine- $N$-oxides are excellent hydrogen bond acceptors and their $\mathrm{H}$-bonding abilities can be influenced by substitution patterns on the pyridine ring (more so than pyridine). $\mathrm{N}$-Oxidation also accounts for a marked 
Table 1. Binding Data

\begin{tabular}{|c|c|c|}
\hline Compound & $\mathrm{R}^{3}$ & $K_{\mathrm{i}}(\mathrm{hSV} 2 \mathrm{~A}, \mathrm{nM})$ \\
\hline $12 a$ & & $4.8^{\mathrm{a}}$ \\
\hline $12 b$ & & 5.1 \\
\hline $12 c$ & & 5.7 \\
\hline $12 d$ & & $6.2^{\mathrm{b}}$ \\
\hline $12 \mathrm{e}$ & & $6.3^{\mathrm{a}}$ \\
\hline $12 f$ & & 8.5 \\
\hline $12 \mathrm{~g}$ & & 13.9 \\
\hline $12 \mathrm{~h}$ & & 23.0 \\
\hline $12 i$ & & 29.9 \\
\hline $12 j$ & & 291 \\
\hline $12 k$ & & 2772 \\
\hline (13) UCB-A & & 1.2 \\
\hline (14) UCB-J & & $2.6^{a}$ \\
\hline (15) SynVesT-1 & & 3.1 \\
\hline (16) UCB-H & & 6.8 \\
\hline (17) SynVesT-2 & & 9.6 \\
\hline $\begin{array}{l}\text { (18) Racemic } \\
\text { SynVesT-1 }\end{array}$ & & $4.9\left(5.1^{c}\right)$ \\
\hline
\end{tabular}

$a_{\mathrm{n}}=2 .{ }^{b}$ It must be noted that while the $K_{\mathrm{i}}$ values for $12 \mathrm{a}$ and $\mathbf{1 2 \mathrm { f }}$ are statistically different, the intermediate $K_{\mathrm{i}}$ for $\mathbf{1 2 d}$ cannot necessarily be distinguished from either using our current data. ${ }^{c}$ Patel et al. ${ }^{16}$ decrease in lipophilicity by comparison with corresponding pyridines, ${ }^{17}$ and differences between the $\pi$-electronic structures of pyridine vs pyridine- $N$-oxide are known. ${ }^{20}$ One might also take into account the bond length of the $N$-oxide, which could be contributing to this loss in affinity.

2.2. The Effect of Hydrocarbons. Removal of the 3-methyl group on the pyridinylmethyl moiety of racemic SynVesT-1 (18, $4.9 \mathrm{nM}$ ) showed no improvement in affinity (12e, $6.3 \mathrm{nM}$ (avg, $n$ $=2)$ ). This appears to be consistent with results from previous studies in the 3,4,5-trifluorophenyl pyrrolidinone series. ${ }^{3}$ Replacing the methyl group with hydrocarbons containing two carbon units of different hybridizations (ethynyl, ethenyl, and ethyl) resulted in a clear affinity trend. The ethynyl (sp1) derivative was the most potent (12a, $4.8 \mathrm{nM}($ avg, $\mathrm{n}=2)$ ), followed by ethenyl (sp2, 12d, 6.2 nM), and ethyl (sp3, 12f, 8.5 $\mathrm{nM}$ ) (see footnote $\mathrm{b}$, Table 1.). This set of compounds also shows a trend with respect to Hammett constants. ${ }^{21}$ The $\sigma_{\mathrm{m}}$ constants show a reduction in electron withdrawing potential from ethynyl $\left(\sigma_{\mathrm{m}}=0.21\right)$ to ethenyl $\left(\sigma_{\mathrm{m}}=0.06\right)$ and slight electron donating potential for ethyl $\left(\sigma_{\mathrm{m}}=-0.07\right)$. This trend seems to contradict the hypothesis of hydrogen bond basicity at the pyridinyl nitrogen. ${ }^{17}$ One might envision the opposite trend, where increased electron withdrawing potential would result in weaker hydrogen bonding, thus reducing the potency across the series.

2.3. The Effect of Halogens. Substitution of the pyridinyl 3-methyl group on racemic SynVesT-1 with halogens resulted in a clear trend with respect to affinity. Substitution with iodine and bromine delivered the most potent compounds in the halogen series $12 \mathrm{~b}(5.1 \mathrm{nM})$ and $12 \mathrm{c}(5.7 \mathrm{nM})$, respectively, whereas chlorine and fluorine substitution led to lower affinities: $14 \mathrm{nM}$ for $12 \mathrm{~g}$ and $23 \mathrm{nM}$ for $\mathbf{1 2} \mathrm{h}$, respectively. The observed trend appears to be synchronous with the radius and, in turn, the electronegativity of the halogens (Figure SI-12). Investigations with respect to the $\sigma_{\mathrm{m}}$ constants, ${ }^{21}$ which would seem to be relevant considering the potential effect on the meta-nitrogen as a hydrogen acceptor, show very close electron withdrawing constants across all halogens.

In comparison to racemic SynVesT-1, only the larger halogen substituents in place of the pyridinyl 3-methyl compete in affinity (I (12b), $5.1 \mathrm{nM}$; $\mathrm{Br}(12 \mathrm{c}), 5.7 \mathrm{nM})$. With respect to electronic influences on the pyridinyl ring, methyl shows only a slightly donating $\sigma_{\mathrm{m}}$ value $\left(\sigma_{\mathrm{m}}=-0.07\right)$, but it is comparable to these halogens in surface area ${ }^{22}$ (Figure 3 ), which could play a role in potency. Finally, the results of the chloro and fluoro analogs when compared to racemic SynVesT-1 show a reduction in affinity. An interesting comparison is the 3-fluoropyridinyl

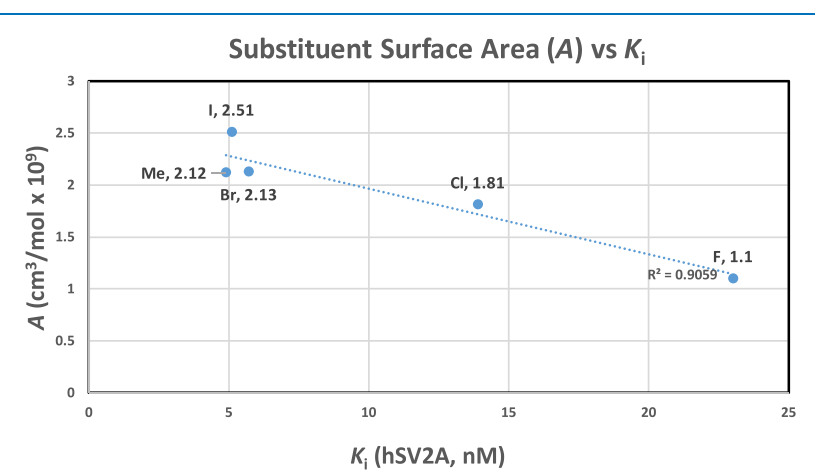

Figure 3. Relationship of the pyridinyl substituent surface area with potency. 
analog of this series (3,5-difluorophenyl) with the 3,4,5trifluorophenyl series. The 3,4,5-trifluorophenyl series shows a much less pronounced decrease in affinity when substituting the 3-methyl pyridinyl with fluorine, i.e., between racemic UCB-J $(5.4 \mathrm{nM})$ and racemic UCB-H $(12.0 \mathrm{nM}) .^{16}$

Ullrich $^{23}$ investigated the $\mathrm{N}$-oxidation of pyridine and related compounds using Agrocybe aegerita peroxidase/peroxygenase ( $\mathrm{AaP})$, a fungal enzyme that has been found to efficiently and selectively transfer oxygen to naphthalene and other aromatic substrates. AaP oxidized the pyridinyl nitrogen in the presence of $\mathrm{H}_{2} \mathrm{O}_{2}$ in $100 \%$ yield taking into account volatilized pyridine, which accounted for a $14 \%$ loss of the starting material (e.g., $86 \%$ yield, $100 \%$ relative conversion). One part of this study showed that pyridine derivatives substituted at the meta-position by different halogens were oxidized at the nitrogen in decreasing yields as the electronegativity of the halogen increased: I (102\%), Br (62\%), $\mathrm{Cl}$ (47\%), and $\mathrm{F}$ (39\%). These results support a trend demonstrating loss of electron density at pyridine/nitrogen (less readily oxidized) with increasing electronegativity of the halogen and, in turn, a decrease in potency. This helps support a hypothesis where decreased hydrogen bonding ability occurs as the electron withdrawing potential of the halogen increases.

2.4. Supporting Trends across all Compounds. 2.4.1. Surface Area of Substituents at the 3-Position of the Pyridinylmethyl Moiety. One observed trend across all of the above compounds is the surface area $(A)$ of the bound moieties at the 3-position of the pyridinyl group. ${ }^{22}$ When using 3-methyl as a reference $\left(A=2.12 \mathrm{~cm}^{3} / \mathrm{mol} \times 10^{9}\right)$, the highest potencies are observed with compounds closest to this surface area (e.g., I and $\mathrm{Br}$ ). This trend shows less sensitivity across the hydrocarbons than with halogens where the potency drops off more rapidly with deviation from this surface area (Figure SI-13).

2.4.2. Bioisosteric Equivalence and the Potential for Additional Hydrogen Bonding. Considering all the compounds reported here, the (3-ethynylpyridin-4-yl)methyl derivative (12a, $4.8 \mathrm{nM}$ ) showed the highest SV2A affinity and was virtually equivalent to our lead compound racemic SynVesT-1 $(18,4.9 \mathrm{nM})$ in potency. Bioisosteric equivalents of the ethynyl moiety are known and several of those (I, Br, and ethenyl) have been utilized in this work. ${ }^{24}$ Our data demonstrates a bioisosteric relationship across our SAR study, and this relationship is most pronounced when comparing the 3-ethynyl, ethenyl, Br, and I substitutions (Table 1). One hypothesis with respect to all of these isosteres is their potential to act as a hydrogen donor or the equivalent and can interact with a hydrogen bond acceptor. ${ }^{24-26}$

Although further investigation would be necessary to provide more detailed insights, it seems reasonable to say that although similar affinities are observed between the halogens and the hydrocarbons, these similar affinities could be related to a different balance between bonding interactions at the pyridinyl 3 -position and pyridine nitrogen. One example derived from computer modeling studies suggests the nitrogen in 3iodopyridine withdraws electron density from the iodine and increases its sigma-hole, thus making it more accessible for hydrogen bonding. ${ }^{25}$ In this model that involves computer generated electrostatic potentials, 3-iodopyridine exhibits a donor-acceptor motif with iodine acting as a donor and the pyridine nitrogen as an acceptor. Although the 3-ethynyl pyridinyl model may resemble this to some extent, it could have significantly different electronic properties yet still result in similar potency through a different donor-acceptor balance. $\pi$ interactions might also be considered. ${ }^{26}$

2.5. Potential Applications in PET/SPECT Imaging. The iodine analog $(\mathbf{1 2 b}, 5.1 \mathrm{nM})$ could be radiolabeled with beta, gamma ray, and positron-emitting isotopes for autoradiography, SPECT, and PET imaging, respectively.

Radionuclides of iodine are widely used in nuclear medicine. Some applications include labeling of receptors, monoclonal antibodies, proteins, etc. These diagnostic and therapeutic applications require quantitative imaging that may extend for several days. ${ }^{131} \mathrm{I}$ is often used for therapy due to its beta emission $(606 \mathrm{keV})$ and emits gamma photons that can be used in SPECT imaging. ${ }^{123} \mathrm{I}$ is suitable for SPECT imaging with a gamma emission peak of $159 \mathrm{keV}$. This peak emission is close to that of ${ }^{99 \mathrm{~m}} \mathrm{Tc}(140 \mathrm{keV})$ for which most SPECT camera design has been optimized. It has a relatively short half-life $(13.22 \mathrm{~h})$, which is favorable for the study of short metabolic processes. ${ }^{124} \mathrm{I}$ is attracting increasing interest for long-term clinical and PET studies. ${ }^{124} \mathrm{I}$ is a positron-emitting nuclide with a half-life of 4.2 days, and about $23 \%$ of disintegrations result in high energy positron emissions. ${ }^{27,28}$ Due to the optimal energy of emitted electrons, ${ }^{125} \mathrm{I}$ is commonly used in autoradiographic studies. ${ }^{29}$ Thus, further in vitro and in vivo characterization of this SV2A ligand as a nuclear imaging agent is warranted.

\section{CONCLUSIONS}

A potent series of SV2A ligands has been discovered based on the racemic SynVesT-1 scaffold. Some of these analogs meet racemic SynVesT-1 in SV2A affinity, and several trends have been observed when comparing affinity against substituent properties in an effort to gain further insights into a previously published hydrogen bonding model. Linear potency trends are evident for the 3-halo pyridinyls with respect to the surface area, van der Waals radius, and electronegativity. Hammett constants $\left(\sigma_{\mathrm{m}}\right)$ are virtually equivalent across the halogens and do not show a linear relationship with affinity. Hydrocarbons show highly linear trends when comparing surface areas or Hammett constants against affinity. The 3-alkynyl pyridinyl derivative showed the highest affinity and affinity decreased across the hydrocarbons as hybridization increased. Affinity loss was observed when the pyridinyl nitrogen of racemic SynVesT-1 was moved to neighboring positions on the ring or oxidized, possibly indicating an influence on hydrogen bonding.

A bioisosteric trend appears to exist across the alkynyl, alkenyl, iodo, and bromo analogs, leaving opportunities for SAR exploration, and we envision an opportunity for additional bonding of these analogs at the 3-position of pyridinyl through sigma-hole bonding of the halogens or the alkynyl hydrogen. It remains unclear exactly which similarities across these new analogs are responsible for their comparable SV2A affinity to racemic SynVesT-1, which leaves much room for further exploration.

\section{EXPERIMENTAL SECTION}

4.1. General Chemistry Information. All reagents and solvents were obtained from commercial sources and used without further purification unless noted otherwise. Nuclear magnetic resonance $\left({ }^{1} \mathrm{H}\right)$ spectra were recorded on an Agilent DD2 $400 \mathrm{MHz}$ (A400a or c) NMR spectrometer. Chemical shifts are reported in parts per million, with the solvent resonance as the internal standard $\left(\mathrm{CDCl}_{3}: 7.26 \mathrm{ppm}\right.$; DMSO$\left.d_{6}: 2.50 \mathrm{ppm}\right)$. The following abbreviations are used to denote 
signal patterns: $\mathrm{s}=$ singlet, $\mathrm{d}=$ doublet, $\mathrm{t}=$ triplet, $\mathrm{m}=$ multiplet, and $\mathrm{br}=$ broad. High-resolution mass spectrometry (HRMS) was performed on a Thermo Scientific (Waltham, MA) LTQ Orbitrap ELITE mass spectrometer. Unless otherwise noted, flash chromatography was conducted by utilizing the Isolera Prime flash purification system from Biotage Inc. and SiliCycle, SliliaSep disposable normal-phase silica gel flash columns (4$120 \mathrm{~g}$ ). Thin-layer chromatography was performed using $2.5 \mathrm{~cm}$ $\times 7.5 \mathrm{~cm}$ glass-backed TLC silica gel 60 F254 plates from EMD Millipore corporation (HX84750394) and visualized by UV light. The purity of all exemplified compounds was $\geq 95 \%$, as determined by HPLC analysis and ${ }^{1} \mathrm{H}$ NMR.

4.1.1. (3-Ethynylpyridin-4-yl)methyl Methanesulfonate (11a). To a solution containing (3-ethynylpyridin-4-yl)methanol (22, $53 \mathrm{mg}, 0.398 \mathrm{mmol})$, TEA $(222 \mu \mathrm{L}, 1.592$ $\mathrm{mmol})$, and DCM (4 mL) was added methanesulfonyl chloride (34.1 $\mu \mathrm{L}, 0.438 \mathrm{mmol})$ dropwise at $\mathrm{rt}$. The solution was maintained for $1 \mathrm{~h}$, diluted with DCM $(15 \mathrm{~mL})$, and washed with saturated sodium bicarbonate $(10 \mathrm{~mL})$. The organic portion was dried over sodium sulfate, filtered, and concentrated to a black residue. Purification on silica gel (0-70\% EtOAc/ Hex) afforded (3-ethynylpyridin-4-yl)methyl methanesulfonate (11a, $30 \mathrm{mg}, 36 \%$ ) as a clear residue that quickly turned purple red. The product was used immediately in the reaction leading to $12 \mathrm{a}$ by diluting in THF and transferring.

4.1.2. (3-lodopyridin-4-yl)methyl Methanesulfonate (11b). To a solution containing (3-iodopyridin-4-yl)methanol (20, 100 $\mathrm{mg}, 0.425 \mathrm{mmol})$, TEA (237 $\mu \mathrm{L}, 1.702 \mathrm{mmol})$, and DCM (2.4 $\mathrm{mL})$ was added methanesulfonyl chloride (36.5 $\mu \mathrm{L}, 0.468$ $\mathrm{mmol}$ ) dropwise at $\mathrm{rt}$. The solution was maintained for $1 \mathrm{~h}$. The solution was concentrated to about $1.5 \mathrm{~mL}$ and loaded directly on to a $25 \mathrm{~g}$ silica gel flash column pre-equilibrated with hexanes. The product was eluted using $0-70 \%$ EtOAc/Hex. The combined fractions containing (3-iodopyridin-4-yl)methyl methanesulfonate $(\mathbf{1 1 b})$ were concentrated to approximately $2 \mathrm{~mL}$ volume and used immediately as a solution in the reaction leading to $\mathbf{1 2 b}$.

4.1.3. (3-Vinylpyridin-4-yl)methyl Methanesulfonate (11d). To a solution containing (3-vinylpyridin-4-yl)methanol (23, $100 \mathrm{mg}, 0.740 \mathrm{mmol})$, TEA (309 $\mu \mathrm{L}, 2.22 \mathrm{mmol}$ ), and DCM $(6 \mathrm{~mL})$ was added methanesulfonyl chloride $(63.4 \mu \mathrm{L}$, $0.814 \mathrm{mmol}$ ) dropwise at $\mathrm{rt}$. The solution was maintained for 1 h, diluted with DCM $(20 \mathrm{~mL})$, and washed with saturated sodium bicarbonate $(10 \mathrm{~mL})$. The organic portion was dried over sodium sulfate and filtered. The solution was concentrated to about $2 \mathrm{~mL}$ and loaded on to a $25 \mathrm{~g}$ silica gel flash column preequilibrated with hexanes. The product was eluted using $100 \%$ EtOAc. The combined fractions containing (3-vinylpyridin-4yl)methyl methanesulfonate (11d) were concentrated to approximately $2 \mathrm{~mL}$ volume and used immediately as a solution in the reaction leading to $\mathbf{1 2 d}$.

4.1.4. 4-(3,5-Difluorophenyl)-1-((3-ethynylpyridin-4-yl)methyl)pyrrolidin-2-one (12a). Compound 12a was prepared as described for $\mathbf{1 2 b}$ using 4-(3,5-difluorophenyl)pyrrolidin-2one $(10,50 \mathrm{mg}, 0.254 \mathrm{mmol})$, sodium hydride $(15.21 \mathrm{mg}, 0.380$ mmol, 60\%), tetrabutylammonium iodide (4.68 mg, 0.013 mmol), and (3-ethynylpyridin-4-yl)methyl methanesulfonate (11a, $30 \mathrm{mg}, 0.142 \mathrm{mmol}$ ). Purification using silica gel flash chromatography (EtOAc/EtOH 0-10\%) afforded 4-(3,5difluorophenyl)-1-((3-ethynylpyridin-4-yl)methyl)pyrrolidin2-one (12a, $24 \mathrm{mg}, 30 \%)$ as a brown residue. ${ }^{1} \mathrm{H}$ NMR (400 $\left.\mathrm{MHz}, \mathrm{CDCl}_{3}\right) \delta: 8.72(\mathrm{~s}, 1 \mathrm{H}), 8.54(\mathrm{~d}, J=5.1 \mathrm{~Hz}, 1 \mathrm{H}), 7.22(\mathrm{~d}, J$ $=5.1 \mathrm{~Hz}, 1 \mathrm{H}), 6.77-6.63(\mathrm{~m}, 3 \mathrm{H}), 4.82-4.57(\mathrm{~m}, 2 \mathrm{H}), 3.69$ (dd, $J=9.7,8.2 \mathrm{~Hz}, 1 \mathrm{H}), 3.64-3.53(\mathrm{~m}, 1 \mathrm{H}), 3.47(\mathrm{~s}, 1 \mathrm{H}), 3.30$ (dd, $J=9.7,6.8 \mathrm{~Hz}, 1 \mathrm{H}), 2.90(\mathrm{dd}, J=17.0,8.9 \mathrm{~Hz}, 1 \mathrm{H}), 2.58$ (dd, $J=17.0,8.2 \mathrm{~Hz}, 1 \mathrm{H})$. HRMS calcd for $\mathrm{C}_{18} \mathrm{H}_{14} \mathrm{~F}_{2} \mathrm{~N}_{2} \mathrm{O}(\mathrm{M}+$ $\mathrm{H})^{+}, 313.1147$, found 313.1151 .

4.1.5. 4-(3,5-Difluorophenyl)-1-((3-iodopyridin-4-yl)methyl)pyrrolidin-2-one (12b). To a solution containing 4(3,5-difluorophenyl)pyrrolidin-2-one $(10,50 \mathrm{mg}, 0.254 \mathrm{mmol})$ and THF $(1.7 \mathrm{~mL})$, cooled to $0{ }^{\circ} \mathrm{C}$, was added sodium hydride ( $15.21 \mathrm{mg}, 0.380 \mathrm{mmol}, 60 \%)$ in one portion (gas evolution). The light tan mixture was removed from cooling and allowed to stir at ambient temperature for $1 \mathrm{~h}$. A solution $(\sim 2 \mathrm{~mL})$ containing (3-iodopyridin-4-yl)methyl methanesulfonate (11b, approximately $133 \mathrm{mg}, 0.425 \mathrm{mmol}$ ) in EtOAc/Hex was added followed by tetrabutylammonium iodide (4.68 mg, 0.013 mmol). The light tan mixture was allowed to stir at rt. After $18 \mathrm{~h}$, the reaction was quenched with two drops of water, concentrated to about half volume and directly loaded on to a 25 g silica gel flash column pre-equilibrated with EtOAc. The product was eluted with EtOAc/EtOH 0-10\%. This afforded 4(3,5-difluorophenyl)-1-((3-iodopyridin-4-yl)methyl)pyrrolidin-2-one (12b, $51 \mathrm{mg}, 49 \%)$ as a dark purple residue. ${ }^{1} \mathrm{H}$ NMR (400 MHz, $\left.\mathrm{CDCl}_{3}\right) \delta: 8.92(\mathrm{~s}, 1 \mathrm{H}), 8.49(\mathrm{~d}, J=5.0 \mathrm{~Hz}$, $1 \mathrm{H}), 7.16(\mathrm{~d}, J=4.9 \mathrm{~Hz}, 1 \mathrm{H}), 6.72(\mathrm{ddd}, J=11.8,6.5,2.1 \mathrm{~Hz}$, $3 \mathrm{H}), 4.70-4.40(\mathrm{~m}, 2 \mathrm{H}), 3.71$ (dd, $J=9.4,8.2 \mathrm{~Hz}, 1 \mathrm{H}), 3.68-$ $3.57(\mathrm{~m}, 1 \mathrm{H}), 3.32(\mathrm{dd}, J=9.4,6.8 \mathrm{~Hz}, 1 \mathrm{H}), 2.92(\mathrm{dd}, J=17.0$, $8.8 \mathrm{~Hz}, 1 \mathrm{H}), 2.61(\mathrm{dd}, J=17.0,8.3 \mathrm{~Hz}, 1 \mathrm{H})$. HRMS calcd for $\mathrm{C}_{16} \mathrm{H}_{13} \mathrm{~F}_{2} \mathrm{IN}_{2} \mathrm{O}(\mathrm{M}+\mathrm{H})^{+}, 415.0113$, found 415.0117 .

4.1.6. 1-((3-Bromopyridin-4-yl)methyl)-4-(3,5difluorophenyl)pyrrolidin-2-one (12c). Compound 12c was prepared as described for 12e using 4-(3,5-difluorophenyl)pyrrolidin-2-one $(10,75 \mathrm{mg}, 0.380 \mathrm{mmol})$, sodium hydride (22.82 mg, $0.571 \mathrm{mmol}, 60 \%)$, 3-bromo-4-(chloromethyl)pyridine hydrochloride (11c, $111 \mathrm{mg}, 0.456 \mathrm{mmol}$ ), and tetrabutylammonium iodide $(7.02 \mathrm{mg}, 0.019 \mathrm{mmol})$. Purification using silica gel flash chromatography (EtOAc/EtOH 0$10 \%)$ afforded 1-((3-bromopyridin-4-yl)methyl)-4-(3,5difluorophenyl)pyrrolidin-2-one (12c, $10 \mathrm{mg}, 7 \%$ ) as a purple/tan residue. ${ }^{1} \mathrm{H}$ NMR $\left(400 \mathrm{MHz}, \mathrm{CDCl}_{3}\right) \delta: 8.70$ (s, $1 \mathrm{H}), 8.48$ (d, $J=4.9 \mathrm{~Hz}, 1 \mathrm{H}), 7.17$ (d, $J=5.0 \mathrm{~Hz}, 1 \mathrm{H}), 6.77-$ $6.64(\mathrm{~m}, 3 \mathrm{H}), 4.73-4.48(\mathrm{~m}, 2 \mathrm{H}), 3.70(\mathrm{dd}, J=9.6,8.2 \mathrm{~Hz}, 1 \mathrm{H})$, $3.60(\mathrm{p}, J=8.2 \mathrm{~Hz}, 1 \mathrm{H}), 3.31(\mathrm{dd}, J=9.5,6.9 \mathrm{~Hz}, 1 \mathrm{H}), 2.89$ (dd, $J=17.0,8.9 \mathrm{~Hz}, 1 \mathrm{H}), 2.58(\mathrm{dd}, J=17.0,8.3 \mathrm{~Hz}, 1 \mathrm{H})$. HRMS calcd for $\mathrm{C}_{16} \mathrm{H}_{13} \mathrm{BrF}_{2} \mathrm{~N}_{2} \mathrm{O}(\mathrm{M}+\mathrm{H})^{+}, 367.0252$, found 367.0259 .

4.1.7. 4-(3,5-Difluorophenyl)-1-((3-vinylpyridin-4-yl)methyl)pyrrolidin-2-one (12d). Compound 12d was prepared as described for 12b using 4-(3,5-difluorophenyl)pyrrolidin-2one $(10,75 \mathrm{mg}, 0.380 \mathrm{mmol})$, sodium hydride $(22.82 \mathrm{mg}, 0.571$ mmol, 60\%), (3-vinylpyridin-4-yl)methyl methanesulfonate (11d, approximately $158 \mathrm{mg}, 0.741 \mathrm{mmol}$ ), and tetrabutylammonium iodide $(7.02 \mathrm{mg}, 0.019 \mathrm{mmol})$. Purification using silica gel flash chromatography (EtOAc/EtOH 0-10\%) afforded 4(3,5-difluorophenyl)-1-((3-vinylpyridin-4-yl)methyl)pyrrolidin-2-one (12d, $40 \mathrm{mg}, 34 \%)$ as a brown oil. ${ }^{1} \mathrm{H}$ NMR $\left(400 \mathrm{MHz}, \mathrm{CDCl}_{3}\right) \delta: 8.71(\mathrm{~s}, 1 \mathrm{H}), 8.48(\mathrm{~d}, J=5.0 \mathrm{~Hz}, 1 \mathrm{H})$, $7.11(\mathrm{~d}, J=5.0 \mathrm{~Hz}, 1 \mathrm{H}), 6.90(\mathrm{dd}, J=17.4,11.1 \mathrm{~Hz}, 1 \mathrm{H}), 6.75-$ $6.60(\mathrm{~m}, 3 \mathrm{H}), 5.75(\mathrm{dd}, J=17.4,1.1 \mathrm{~Hz}, 1 \mathrm{H}), 5.49(\mathrm{dd}, J=11.1$, $1.1 \mathrm{~Hz}, 1 \mathrm{H}), 4.69-4.48(\mathrm{~m}, 2 \mathrm{H}), 3.54(\mathrm{td}, J=7.8,7.4,3.4 \mathrm{~Hz}$, $2 \mathrm{H}), 3.15$ (q, $J=2.4 \mathrm{~Hz}, 1 \mathrm{H}), 2.97-2.82(\mathrm{~m}, 1 \mathrm{H}), 2.62-2.45$ $(\mathrm{m}, 1 \mathrm{H})$. HRMS calcd for $\mathrm{C}_{18} \mathrm{H}_{16} \mathrm{~F}_{2} \mathrm{~N}_{2} \mathrm{O}(\mathrm{M}+\mathrm{H})^{+}$, 315.1303, found 315.1304 .

4.1.8. 4-(3,5-Difluorophenyl)-1-(pyridin-4-ylmethyl)pyrrolidin-2-one (12e). To a solution containing 4-(3,5difluorophenyl)pyrrolidin-2-one $(\mathbf{1 0}, 75 \mathrm{mg}, 0.380 \mathrm{mmol})$ and 
THF $(2.5 \mathrm{~mL})$, cooled to $0{ }^{\circ} \mathrm{C}$, was added sodium hydride $(38.0$ $\mathrm{mg}, 0.951 \mathrm{mmol}, 60 \%)$ in one portion (gas evolution). The mixture was removed from cooling and allowed to stir at ambient temperature for $1 \mathrm{~h}$. 4-(Chloromethyl)pyridine hydrochloride (11e, $68.6 \mathrm{mg}, 0.418 \mathrm{mmol}$ ) was added followed by tetrabutylammonium iodide $(7.02 \mathrm{mg}, 0.019 \mathrm{mmol})$. The mixture was allowed to stir for $18 \mathrm{~h}$, carefully added to saturated $\mathrm{NaHCO}_{3}(15 \mathrm{~mL})$, and the resultant aqueous solution was extracted with EtOAc $(2 \times 15 \mathrm{~mL})$. The combined organic portions were washed with brine $(15 \mathrm{~mL})$, dried over sodium sulfate, filtered, and concentrated. Purification using silica gel flash chromatography (EtOAc/EtOH 0-10\%) afforded 4-(3,5difluorophenyl)-1-(pyridin-4-ylmethyl)pyrrolidin-2-one (12e, $30 \mathrm{mg}, 27 \%)$ as a purple residue. ${ }^{1} \mathrm{H}$ NMR $(400 \mathrm{MHz}$, $\left.\mathrm{CDCl}_{3}\right) \delta: 8.64-8.52(\mathrm{~m}, 2 \mathrm{H}), 7.22-7.11(\mathrm{~m}, 2 \mathrm{H}), 6.70(\mathrm{td}, J=$ 6.1, 5.5, $2.7 \mathrm{~Hz}, 3 \mathrm{H}), 4.63-4.37$ (m, 2H), 3.70-3.49 (m, $2 \mathrm{H})$, $3.27(\mathrm{dd} J=9.3,6.5 \mathrm{~Hz}, 1 \mathrm{H}), 2.91(\mathrm{dd}, J=17.0,8.8 \mathrm{~Hz}, 1 \mathrm{H})$, 2.59 (dd, $J=17.0,8.0 \mathrm{~Hz}, 1 \mathrm{H})$. HRMS calcd for $\mathrm{C}_{16} \mathrm{H}_{14} \mathrm{~F}_{2} \mathrm{~N}_{2} \mathrm{O}$ $(\mathrm{M}+\mathrm{H})^{+}, 289.1147$, found 289.1141 .

4.1.9. 4-(3,5-Difluorophenyl)-1-((3-ethylpyridin-4-yl)methyl)pyrrolidin-2-one (12f). To a degassed solution containing 4-(3,5-difluorophenyl)-1-((3-ethynylpyridin-4-yl)methyl)pyrrolidin-2-one (12a, $50 \mathrm{mg}, 0.160 \mathrm{mmol}$ ) and EtOAc $(1.6 \mathrm{~mL})$ was added palladium on carbon $(10 \%, 8.52$ $\mathrm{mg}, 8.00 \mu \mathrm{mol})$. The mixture was stirred quickly for $90 \mathrm{~min}$ at $\mathrm{rt}$ under an $\mathrm{H}_{2}$ balloon. The reaction was filtered through celite (500 mesh, fine, acid washed) and the $\mathrm{Pd} / \mathrm{C}$ was rinsed thoroughly with EtOAc on the Celite. The filtered solution/ washes were concentrated to afford 4-(3,5-difluorophenyl)-1((3-ethylpyridin-4-yl)methyl)pyrrolidin-2-one (12f, $50 \mathrm{mg}$, $99 \%)$ as a clear, oily residue. ${ }^{1} \mathrm{H}$ NMR $\left(400 \mathrm{MHz}, \mathrm{CDCl}_{3}\right) \delta$ : $8.50-8.38(\mathrm{~m}, 2 \mathrm{H}), 7.06(\mathrm{~d}, J=5.0 \mathrm{~Hz}, 1 \mathrm{H}), 6.70(\mathrm{pd}, J=4.2$, $1.9 \mathrm{~Hz}, 3 \mathrm{H}), 4.56(\mathrm{dd}, J=89.5,15.4 \mathrm{~Hz}, 2 \mathrm{H}), 3.66-3.51(\mathrm{~m}$, $2 \mathrm{H}), 3.29-3.18(\mathrm{~m}, 1 \mathrm{H}), 2.98-2.85(\mathrm{~m}, 1 \mathrm{H}), 2.70(\mathrm{q}, J=7.6$ $\mathrm{Hz}, 2 \mathrm{H}), 2.66-2.54(\mathrm{~m}, 1 \mathrm{H}), 1.25(\mathrm{td}, J=7.4,2.1 \mathrm{~Hz}, 3 \mathrm{H})$. HRMS calcd for $\mathrm{C}_{18} \mathrm{H}_{18} \mathrm{~F}_{2} \mathrm{~N}_{2} \mathrm{O}(\mathrm{M}+\mathrm{H})^{+}, 317.1460$, found 317.1457.

4.1.10. 1-((3-Chloropyridin-4-yl)methyl)-4-(3,5difluorophenyl)pyrrolidin-2-one (12g). Compound $12 \mathrm{~g}$ was prepared as described for 12e using 4-(3,5-difluorophenyl)pyrrolidin-2-one $(\mathbf{1 0}, 50 \mathrm{mg}, 0.254 \mathrm{mmol})$, sodium hydride (15 $\mathrm{mg}, 0.380 \mathrm{mmol}, 60 \%)$, 4-(bromomethyl)-3-chloropyridine hydrobromide $(11 \mathrm{~g}, 87 \mathrm{mg}, 0.304 \mathrm{mmol})$, and tetrabutylammonium iodide $(4.7 \mathrm{mg}, 0.013 \mathrm{mmol})$. Purification using silica gel flash chromatography (EtOAc/EtOH 0-10\%) afforded 1-((3chloropyridin-4-yl)methyl)-4-(3,5-difluorophenyl)pyrrolidin-2one $(12 \mathrm{~g}, 4 \mathrm{mg}, 5 \%)$ as a clear residue. ${ }^{1} \mathrm{H}$ NMR $(400 \mathrm{MHz}$, $\left.\mathrm{CDCl}_{3}\right) \delta: 8.58(\mathrm{~d}, J=11.2 \mathrm{~Hz}, 1 \mathrm{H}), 8.46(\mathrm{dd}, J=16.1,5.0 \mathrm{~Hz}$, $1 \mathrm{H}), 7.21(\mathrm{~d}, J=4.9 \mathrm{~Hz}, 1 \mathrm{H}), 6.78-6.65(\mathrm{~m}, 3 \mathrm{H}), 4.77-4.52$ $(\mathrm{m}, 2 \mathrm{H}), 3.72(\mathrm{dd}, J=9.6,8.2 \mathrm{~Hz}, 1 \mathrm{H}), 3.67-3.55(\mathrm{~m}, 1 \mathrm{H}), 3.32$ (dd, $J=9.5,6.9 \mathrm{~Hz}, 1 \mathrm{H}), 2.91(\mathrm{dd}, J=17.0,8.9 \mathrm{~Hz}, 1 \mathrm{H}), 2.60$ (dd, $J=17.0,8.3 \mathrm{~Hz}, 1 \mathrm{H})$. HRMS calcd for $\mathrm{C}_{16} \mathrm{H}_{13} \mathrm{ClF}_{2} \mathrm{~N}_{2} \mathrm{O}(\mathrm{M}$ $+\mathrm{H})^{+}, 323.0757$, found 323.0761 .

4.1.11. 4-(3,5-Difluorophenyl)-1-((3-fluoropyridin-4-yl)methyl)pyrrolidin-2-one (12h). Compound $12 \mathrm{~h}$ was prepared as described for 12e using 4-(3,5-difluorophenyl)pyrrolidin-2one $(10,50 \mathrm{mg}, 0.254 \mathrm{mmol})$, sodium hydride (15 mg, 0.380 mmol, 60\%), 4-(chloromethyl)-3-fluoropyridine hydrochloride (11 h, $55 \mathrm{mg}, 0.304 \mathrm{mmol}$ ), and tetrabutylammonium iodide (4.7 mg, $0.013 \mathrm{mmol}$ ). Purification using silica gel flash chromatography (EtOAc/EtOH $0-10 \%)$ afforded 4-(3,5difluorophenyl)-1-((3-fluoropyridin-4-yl)methyl)pyrrolidin-2one (12h, $25 \mathrm{mg}, 32 \%)$ as a purple/tan residue. ${ }^{1} \mathrm{H}$ NMR (400
$\left.\mathrm{MHz}, \mathrm{CDCl}_{3}\right) \delta: 8.47(\mathrm{~s}, 1 \mathrm{H}), 8.41(\mathrm{~d}, J=4.8 \mathrm{~Hz}, 1 \mathrm{H}), 7.32-$ $7.21(\mathrm{~m}, 1 \mathrm{H}), 6.71(\mathrm{dd} J=6.7,3.2 \mathrm{~Hz}, 3 \mathrm{H}), 4.60(\mathrm{q}, J=15.4 \mathrm{~Hz}$, $2 \mathrm{H}), 3.80-3.66(\mathrm{~m}, 1 \mathrm{H}), 3.59(\mathrm{p}, J=8.2 \mathrm{~Hz}, 1 \mathrm{H}), 3.32(\mathrm{dd}, J=$ 9.6, $6.9 \mathrm{~Hz}, 1 \mathrm{H}), 2.88(\mathrm{dd}, J=17.0,9.0 \mathrm{~Hz}, 1 \mathrm{H}), 2.56(\mathrm{dd}, J=$ 17.0, 8.2 Hz, 1H). HRMS calcd for $\mathrm{C}_{16} \mathrm{H}_{13} \mathrm{~F}_{3} \mathrm{~N}_{2} \mathrm{O}(\mathrm{M}+\mathrm{H})^{+}$, 307.1053, found 307.1053.

4.1.12. 4-(3,5-Difluorophenyl)-1-((2-methylpyridin-3-yl)methyl)pyrrolidin-2-one (12i): Compound $12 \mathrm{i}$ was prepared as described for 12e using 4-(3,5-difluorophenyl)pyrrolidin-2one $(10,50 \mathrm{mg}, 0.253 \mathrm{mmol})$, sodium hydride $(7.6 \mathrm{mg}, 0.304$ mmol, 95\%), tetrabutylammonium iodide (4.8 mg, 0.013 $\mathrm{mmol}$ ), and 3-(chloromethyl)-2-methylpyridine hydrochloride (11i, $52 \mathrm{mg}, 0.278 \mathrm{mmol}$ ). The mixture was stirred at $\mathrm{rt}$ for $18 \mathrm{~h}$. Purification using silica gel flash chromatography (EtOAc/Hex 90-100\%) afforded 4-(3,5-difluorophenyl)-1-((2-methylpyridin-3-yl)methyl)pyrrolidin-2-one (12i, $51 \mathrm{mg}, 71 \%) .{ }^{1} \mathrm{H}$ NMR $\left(400 \mathrm{MHz}, \mathrm{CDCl}_{3}\right) \delta: 2.54-2.58(\mathrm{~m}, 4 \mathrm{H}), 2.87(\mathrm{dd}, J=16.0 \mathrm{~Hz}$, $J=7.6 \mathrm{~Hz}, 1 \mathrm{H}), 3.18(\mathrm{dd}, J=5.5 \mathrm{~Hz}, J=2.9 \mathrm{~Hz}, 1 \mathrm{H}), 3.50-3.60$ $(\mathrm{m}, 2 \mathrm{H}), 4.42(\mathrm{~d}, J=15.0 \mathrm{~Hz}, 1 \mathrm{H}), 4.62(\mathrm{~d}, J=15.0 \mathrm{~Hz}, 1 \mathrm{H})$, 6.65-6.68 (m, 3H), 7.08-7.13 (m, 1H), 7.44-7.46 (m, $1 \mathrm{H})$, $8.41(\mathrm{~s}, 1 \mathrm{H})$. HRMS calcd for $\mathrm{C}_{17} \mathrm{H}_{16} \mathrm{~F}_{2} \mathrm{~N}_{2} \mathrm{O}(\mathrm{M}+\mathrm{H})^{+}$, 303.1303, found 303.1303.

4.1.13. 4-(3,5-Difluorophenyl)-1-((4-methylpyridin-3-yl)methyl)pyrrolidin-2-one (12j). Compound $12 \mathrm{j}$ was prepared as described for 12e using 4-(3,5-difluorophenyl)pyrrolidin-2one $(10,50 \mathrm{mg}, 0.253 \mathrm{mmol})$, sodium hydride $(7.6 \mathrm{mg}, 0.304$ mmol, 95\%), tetrabutylammonium iodide (4.8 mg, 0.013 mmol), and 3-(bromomethyl)-4-methylpyridine hydro bromide (11j, $77 \mathrm{mg}, 0.278 \mathrm{mmol}$ ). The mixture was stirred at rt for $18 \mathrm{~h}$. Purification using silica gel flash chromatography (EtOAc/Hex 90-100\%) afforded 4-(3,5-difluorophenyl)-1-((4-methylpyridin-3-yl)methyl)pyrrolidin-2-one (12j, $55 \mathrm{mg}, 70 \%) .{ }^{1} \mathrm{H}$ NMR $(400 \mathrm{MHz}, \mathrm{CDCl} 3) \delta: 2.31(\mathrm{~s}, 3 \mathrm{H}), 2.51(\mathrm{dd}, J=17.0 \mathrm{~Hz}, J=7.8$ $\mathrm{Hz}, 1 \mathrm{H}), 2.83(\mathrm{dd}, J=16.9 \mathrm{~Hz}, J=8.7 \mathrm{~Hz}, 1 \mathrm{H}), 3.12-3.16(\mathrm{~m}$, $1 \mathrm{H}), 3.45-3.56(\mathrm{~m}, 2 \mathrm{H}), 4.44(\mathrm{~d}, J=14.9 \mathrm{~Hz}, 1 \mathrm{H}), 4.59$ (d, $J=$ $14.9 \mathrm{~Hz}, 1 \mathrm{H}), 6.60-6.65(\mathrm{~m}, 3 \mathrm{H}), 7.09(\mathrm{~d}, J=4.9 \mathrm{~Hz}, 1 \mathrm{H}), 8.33$ $(\mathrm{s}, 1 \mathrm{H}), 8.37(\mathrm{~d}, J=4.9,1 \mathrm{H})$. HRMS calcd for $\mathrm{C}_{17} \mathrm{H}_{16} \mathrm{~F}_{2} \mathrm{~N}_{2} \mathrm{O}(\mathrm{M}$ $+\mathrm{H})^{+}, 303.1303$, found 303.1305.

4.1.14. 4-((4-(3,5-Difluorophenyl)-2-oxopyrrolidin-1-yl)methyl)-3-methylpyridine 1-oxide (12k). To a solution containing 4-(3,5-difluorophenyl)-1-((3-methylpyridin-4-yl)methyl)pyrrolidin-2-one $(18,25 \mathrm{mg}, 0.083 \mathrm{mmol})$ and THF $(0.83 \mathrm{~mL})$ was added mCPBA $(37.1 \mathrm{mg}, 0.165 \mathrm{mmol})$ at $\mathrm{rt}$ in one portion. The solution was maintained for $3 \mathrm{~h}$ and added to saturated $\mathrm{NaHCO}_{3}(15 \mathrm{~mL})$. The resultant aqueous mixture was extracted with EtOAc $(30 \mathrm{~mL})$. The organic portion was washed with water $(15 \mathrm{~mL})$, washed with brine $(15 \mathrm{~mL})$, dried over $\mathrm{Na}_{2} \mathrm{SO}_{4}$, filtered, and concentrated to a white residue. Purification using silica gel flash chromatography (DCM/ $\mathrm{MeOH}$ 0-10\%) afforded 4-((4-(3,5-difluorophenyl)-2-oxopyrrolidin-1-yl)methyl)-3-methylpyridine 1-oxide (12k, $12 \mathrm{mg}$, $46 \%)$ as a white solid. ${ }^{1} \mathrm{H}$ NMR $\left(400 \mathrm{MHz}, \mathrm{CDCl}_{3}\right) \delta: 8.13-$ $7.97(\mathrm{~m}, 2 \mathrm{H}), 7.06(\mathrm{~d}, J=6.5 \mathrm{~Hz}, 1 \mathrm{H}), 6.77-6.61(\mathrm{~m}, 3 \mathrm{H})$, 4.64-4.30 (m, 2H), 3.61 (ddd, $J=14.7,12.0,7.5 \mathrm{~Hz}, 2 \mathrm{H}), 3.24$ (dd, $J=8.8,6.2 \mathrm{~Hz}, 1 \mathrm{H}), 2.89$ (dd, $J=17.1,8.7 \mathrm{~Hz}, 1 \mathrm{H}), 2.58$ (dd, $J=17.0,7.7 \mathrm{~Hz}, 1 \mathrm{H}), 2.28$ (s, 3H). HRMS calcd for $\mathrm{C}_{17} \mathrm{H}_{16} \mathrm{~F}_{2} \mathrm{~N}_{2} \mathrm{O}_{2}(\mathrm{M}+\mathrm{H})^{+}, 319.1253$, found 319.1257 .

4.1.15. 4-(3,5-Difluorophenyl)-1-((3-methylpyridin-4-yl)methyl)pyrrolidin-2-one (18, Racemic SynVesT-1). Compound 18 (racemic SynVesT-1) was prepared as described for 12e using 4-(3,5-difluorophenyl)pyrrolidin-2-one $(10,100 \mathrm{mg}$, $0.507 \mathrm{mmol}$ ), sodium hydride ( $81 \mathrm{mg}, 2.029 \mathrm{mmol}, 60 \%)$, tetrabutylammonium iodide $(18.7 \mathrm{mg}, 0.051 \mathrm{mmol})$, and 4- 
(chloromethyl)-3-methylpyridine hydrochloride (135 mg, $0.761 \mathrm{mmol})$. The mixture was stirred at $50{ }^{\circ} \mathrm{C}$ for $18 \mathrm{~h}$. Purification using silica gel flash chromatography (EtOAc/ EtOH 0-10\%) afforded 4-(3,5-difluorophenyl)-1-((3-methylpyridin-4-yl)methyl)pyrrolidin-2-one (18, racemic SynVesT-1, $123 \mathrm{mg}, 80 \%)$ as a light purple, oily residue that solidified on standing. ${ }^{1} \mathrm{H}$ NMR $\left(400 \mathrm{MHz}, \mathrm{CDCl}_{3}\right) \delta: 8.42(\mathrm{~d}, J=3.8 \mathrm{~Hz}$, $2 \mathrm{H}), 7.04(\mathrm{~d}, J=4.9 \mathrm{~Hz}, 1 \mathrm{H}), 6.71(\mathrm{tt}, J=5.4,2.4 \mathrm{~Hz}, 3 \mathrm{H})$, $4.68-4.35$ (m, 2H), 3.68-3.52 (m, 2H), 3.24 (hept, $J=5.0,4.4$ $\mathrm{Hz}, 1 \mathrm{H}), 2.98-2.84(\mathrm{~m}, 1 \mathrm{H}), 2.60(\mathrm{dd}, J=17.0,8.0 \mathrm{~Hz}, 1 \mathrm{H})$, $2.31(\mathrm{~s}, 3 \mathrm{H})$.

4.2. Competition Radioligand Binding Assays. Competition radioligand binding assays were run twice independently using separate assay materials. Some compounds were run a second time through this paradigm and are marked with an " $n$ $=2$ " in Table 1 and the Results and Discussion section. Compounds were dissolved in DMSO (Sigma-Aldrich) to a concentration of $10 \mathrm{mM}$. Each $10 \mathrm{mM}$ DMSO stock was serial diluted in PBS at $\mathrm{pH} 7.4$ (Gibco) with $0.1 \%$ BSA to give 12 half$\log$ dilutions from $10 \mu \mathrm{M}$ to $32 \mathrm{pM}$ when added to the assay (20 $\mu \mathrm{L}$ of a $10 \mathrm{X}$ working stock). Fresh frozen human brain (normal donor) was obtained from ABS Bio (Wilmington, DE). Duplicate samples of frontal cortex gray matter were homogenized in PBS at a concentration of $10 \mathrm{mg}$ wet weight per $\mathrm{mL}$ for storage at $-80{ }^{\circ} \mathrm{C}$ and further diluted to $4 \mathrm{mg} / \mathrm{mL}$ in PBS on the day of the assays. The final membrane concentration in the assay was $0.4 \mathrm{mg} / \mathrm{mL}(100 \mu \mathrm{L}$ of $2 \mathrm{X}$ working stock per $200 \mu \mathrm{L}$ reaction $) .\left[{ }^{3} \mathrm{H}\right] \mathrm{UCB}-\mathrm{J}$ was synthesized by rhodium-black mediated hydrogen/tritium exchange to a specific activity of $34.9 \mathrm{Ci} / \mathrm{mmol}$ and a radiochemical purity of $98.9 \%$ and diluted in duplicate to a concentration of $6.25 \mathrm{nM}$ in PBS to give $2.5 \mathrm{X}$ working stocks (the final concentration in the plate was $2.5 \mathrm{nM}$ ). Working stocks of membranes $(100 \mu \mathrm{L})$, blocking compounds $(20 \mu \mathrm{L})$, and radioligand $(80 \mu \mathrm{L})$ were combined in quadruplicate wells of 96-well plates, sealed, and incubated at room temperature on an orbital shaker at 250 RPM for $90 \mathrm{~min}$ to achieve binding equilibrium. Reaction plates were filtered onto Multiscreen GF/B Harvest Plates (Millipore) and rapidly washed with $300 \mathrm{~mL}$ of cold PBS. The plates were allowed to dry, sealed on the bottom, and $40 \mu \mathrm{L}$ of Microscint-20 scintillation cocktail (Perkin-Elmer) was added to all wells before affixing a clear top seal and counting using a Microbeta2 plate reader (Perkin-Elmer). Technical replicates $(n=4)$ from each independent assay were averaged in Microsoft Excel, and the duplicate values for each point were plotted and analyzed in GraphPad Prism using the built-in 1-site $K_{\mathrm{i}}$ model. The curve fitting provided $K_{\mathrm{i}}$ values and $95 \%$ confidence intervals used to compare compounds for statistical differences, indicated by nonoverlapping 95\% confidence bands (Figure SI-14).

\section{ASSOCIATED CONTENT}

\section{SI Supporting Information}

The Supporting Information is available free of charge at https://pubs.acs.org/doi/10.1021/acsomega.1c02433.

NMR spectra (pages S2-S8), experimental details for intermediates leading to $11 \mathbf{a}, \mathbf{1 1} \mathbf{b}$, and $11 \mathbf{d}$ (pages S8S10), scatter plots related to observed potency trends (page S11 and S12), analytical HPLC chromatograms (pages S13-S16) (PDF)

\section{AUTHOR INFORMATION}

Corresponding Authors

Songye Li - PET Center, Yale University School of Medicine, New Haven, Connecticut 06520, United States; 10 orcid.org/ 0000-0002-6096-8756; Email: songye.li@yale.edu

Zhengxin Cai - PET Center, Yale University School of Medicine, New Haven, Connecticut 06520, United States; ๑ orcid.org/0000-0002-2005-6760; Email: jason.cai@ yale.edu

\section{Authors}

Richard Pracitto - PET Center, Yale University School of Medicine, New Haven, Connecticut 06520, United States; Present Address: Present address: Biohaven Labs, Biohaven Pharmaceuticals Inc., New Haven, Connecticut 06510, United States (R.P.)

Kyle C. Wilcox - Translational Imaging Neuroscience, AbbVie, North Chicago, Illinois 60064, United States

Marcel Lindemann - PET Center, Yale University School of Medicine, New Haven, Connecticut 06520, United States; Present Address: Present address: Nuclear Medicine and Radiation Biology Research Group, Department of Clinical Medicine, UiT The Arctic University of Norway, Tromsø, Norway (M.L); Present Address: Present address: The PET Imaging Center, University Hospital of North Norway, Tromsø, Norway (M.L.)

Jie Tong - PET Center, Yale University School of Medicine, New Haven, Connecticut 06520, United States

Chao Zheng - PET Center, Yale University School of Medicine, New Haven, Connecticut 06520, United States; 10 orcid.org/ 0000-0002-2179-8096

Sjoerd J. Finnema - PET Center, Yale University School of Medicine, New Haven, Connecticut 06520, United States; Translational Imaging Neuroscience, AbbVie, North Chicago, Illinois 60064, United States

Yiyun Huang - PET Center, Yale University School of Medicine, New Haven, Connecticut 06520, United States

Complete contact information is available at:

https://pubs.acs.org/10.1021/acsomega.1c02433

\section{Author Contributions}

The manuscript was written through contributions of all authors. All authors have given approval to the final version of the manuscript.

\section{Notes}

The authors declare no competing financial interest.

\section{ACKNOWLEDGMENTS}

This research was supported by NIH K01EB023312 and R01AG058773. Z.C. is an Archer Foundation Research Scientist.

\section{ABBREVIATIONS}

PET, positron emmision tomography; SPECT, single-photon emmision computed tomography; $\mathrm{AD}$, Alzheimer's disease; $\mathrm{PD}$, Parkinson's disease; SAR, structure-activity relationship

\section{REFERENCES}

(1) Cai, Z.; Li, S.; Matuskey, D.; Nabulsi, N.; Huang, Y. PET imaging of synaptic density: A new tool for investigation of neuropsychiatric diseases. Neurosci. Lett. 2019, 691, 44-50. 
(2) Takamori, S. Synaptic Vesicles. In Encyclopedia of Neuroscience; 2009; pp. 801-808, DOI: 10.1016/B978-008045046-9.01392-9.

(3) Mercier, J.; Archen, L.; Bollu, V.; Carré, S.; Evrard, Y.; Jnoff, E.; Kenda, B.; Lallemand, B.; Michel, P.; Montel, F.; Moureau, F.; Price, N.; Quesnel, Y.; Sauvage, X.; Valade, A.; Provins, L. Discovery of heterocyclic nonacetamide synaptic vesicle protein 2A (SV2A) ligands with single-digit nanomolar potency: opening avenues towards the first SV2A positron emission tomography (PET) ligands. Chem. Med. Chem. 2014, 9, 693-698.

(4) Finnema, S. J.; Nabulsi, N. B.; Eid, T.; Detyniecki, K.; Lin, S. F.; Chen, M. K.; Dhaher, R.; Matuskey, D.; Baum, E.; Holden, D.; Spencer, D. D.; Mercier, J.; Hannestad, J.; Huang, Y.; Carson, R. E. Imaging synaptic density in the living human brain. Sci. Transl. Med. 2016, 8, 348 ra96.

(5) Chen, M. K.; Mecca, A. P.; Naganawa, M.; Finnema, S. J.; Toyonaga, T.; Lin, S. F.; Najafzadeh, S.; Ropchan, J.; Lu, Y.; McDonald, J. W.; Michalak, H. R.; Nabulsi, N. B.; Arnsten, A. F. T.; Huang, Y.; Carson, R. E.; van Dyck, C. H. Assessing Synaptic Density in Alzheimer Disease With Synaptic Vesicle Glycoprotein 2A Positron Emission Tomographic Imaging. JAMA Neurol. 2018, 1215.

(6) Matuskey, D.; Tinaz, S.; Wilcox, K. C.; Naganawa, M.; Toyonaga, T.; Dias, M.; Henry, S.; Pittman, B.; Ropchan, J.; Nabulsi, N.; Suridjan, I.; Comley, R. A.; Huang, Y.; Finnema, S. J.; Carson, R. E. Synaptic Changes in Parkinson Disease Assessed with in vivo Imaging. Ann. Neurol. 2020, 87, 329-338.

(7) Holmes, S. E.; Scheinost, D.; Finnema, S. J.; Naganawa, M.; Davis, M. T.; DellaGioia, N.; Nabulsi, N.; Matuskey, D.; Angarita, G. A.; Pietrzak, R. H.; Duman, R. S.; Sanacora, G.; Krystal, J. H.; Carson, R. E.; Esterlis, I. Lower synaptic density is associated with depression severity and network alterations. Nat. Commun. 2019, 10, 1529.

(8) Onwordi, E. C.; Halff, E. F.; Whitehurst, T.; Mansur, A.; Cotel, M.C.; Wells, L.; Creeney, H.; Bonsall, D.; Rogdaki, M.; Shatalina, E.; Reis Marques, T.; Rabiner, E. A.; Gunn, R. N.; Natesan, S.; Vernon, A. C.; Howes, O. D. Synaptic density marker SV2A is reduced in schizophrenia patients and unaffected by antipsychotics in rats. Nat. Commun. 2020, 11, 246.

(9) Nabulsi, N.; Mercier, J.; Holden, D.; Carre, S.; Najafzadeh, S.; Vandergeten, M.-C.; Lin, S.-f.; Deo, A. K.; Price, N.; Wood, M.; LaraJaime, T.; Montel, F.; Laruelle, M.; Carson, R. E.; Hannestad, J.; Huang, Y. Synthesis and Preclinical Evaluation of 11C-UCB-J as a PET Tracer for Imaging the Synaptic Vesicle Glycoprotein 2A in the Brain. J. Nucl. Med. 2016, 777 .

(10) Estrada, S.; Lubberink, M.; Thibblin, A.; Sprycha, M.; Buchanan, T.; Mestdagh, N.; Kenda, B.; Mercier, J.; Provins, L.; Gillard, M.; Tytgat, D.; Antoni, G. [11C]UCB-A, a novel PET tracer for synaptic vesicle protein 2A. Nucl. Med. Biol. 2016, 43, 325-332.

(11) Bastin, C.; Bahri, M. A.; Meyer, F.; Manard, M.; Delhaye, E.; Plenevaux, A.; Becker, G.; Seret, A.; Mella, C.; Giacomelli, F.; Degueldre, C.; Balteau, E.; Luxen, A.; Salmon, E. In vivo imaging of synaptic loss in Alzheimer's disease with $[18 \mathrm{~F}] \mathrm{UCB}-\mathrm{H}$ positron emission tomography. Eur. J. Nucl. Med. Mol. Imaging 2020, 47, 390402.

(12) Warnock, G. I.; Aerts, J.; Bahri, M. A.; Bretin, F.; Lemaire, C.; Giacomelli, F.; Mievis, F.; Mestdagh, N.; Buchanan, T.; Valade, A.; Mercier, J.; Wood, M.; Gillard, M.; Seret, A.; Luxen, A.; Salmon, E.; Plenevaux, A. Evaluation of $18 \mathrm{~F}-\mathrm{UCB}-\mathrm{H}$ as a novel PET tracer for synaptic vesicle protein $2 \mathrm{~A}$ in the brain. J. Nucl. Med. 2014, 55, 13361341.

(13) Li, S.; Cai, Z.; Wu, X.; Holden, D.; Pracitto, R.; Kapinos, M.; Gao, H.; Labaree, D.; Nabulsi, N.; Carson, R. E.; Huang, Y. Synthesis and in Vivo Evaluation of a Novel PET Radiotracer for Imaging of Synaptic Vesicle Glycoprotein 2A (SV2A) in Nonhuman Primates. ACS Chem. Neurosci. 2019, 10, 1544-1554.

(14) Cai, Z.; Li, S.; Zhang, W.; Pracitto, R.; Wu, X.; Baum, E.; Finnema, S. J.; Holden, D.; Toyonaga, T.; Lin, S.-f.; Lindemann, M.; Shirali, A.; Labaree, D. C.; Ropchan, J.; Nabulsi, N.; Carson, R. E.; Huang, Y. Synthesis and Preclinical Evaluation of an ${ }^{18} \mathrm{~F}$-Labeled Synaptic Vesicle Glycoprotein 2A PET Imaging Probe: $\left[{ }^{18} \mathrm{~F}\right]$ SynVesT2. ACS Chem. Neurosci. 2020, 11, 592-603.
(15) Kenda, B. M.; Matagne, A. C.; Talaga, P. E.; Pasau, P. M.; Differding, E.; Lallemand, B. I.; Frycia, A. M.; Moureau, F. G.; Klitgaard, H. V.; Gillard, M. R.; Fuks, B.; Michel, P. Discovery of 4Substituted Pyrrolidone Butanamides as New Agents with Significant Antiepileptic Activity. J. Med. Chem. 2004, 47, 530-549.

(16) Patel, S.; Knight, A.; Krause, S.; Teceno, T.; Tresse, C.; Li, S.; Cai, Z.; Gouasmat, A.; Carroll, V. M.; Barret, O.; Gottmukkala, V.; Zhang, W.; Xiang, X.; Morley, T.; Huang, Y.; Passchier, J. Preclinical In Vitro and In Vivo Characterization of Synaptic Vesicle 2A-Targeting Compounds Amenable to F-18 Labeling as Potential PET Radioligands for Imaging of Synapse Integrity. Mol. Imaging Biol. 2020, 22, 832-841.

(17) Abraham, M. H.; Honcharova, L.; Rocco, S. A.; Acree, W. E., Jr.; De Fina, K. M. The lipophilicity and hydrogen bond strength of pyridine- $\mathrm{N}$-oxides and protonated pyridine- $\mathrm{N}$-oxides. New J. Chem. 2011, 35, 930-936.

(18) Becker, G.; Warnier, C.; Serrano, M. E.; Bahri, M. A.; Mercier, J.; Lemaire, C.; Salmon, E.; Luxen, A.; Plenevaux, A. Pharmacokinetic Characterization of $\left[{ }^{18} \mathrm{~F}\right] \mathrm{UCB}-\mathrm{H}$ PET Radiopharmaceutical in the Rat Brain. Mol. Pharmaceutics 2017, 14, 2719-2725.

(19) Łukomska, M.; Rybarczyk-Pirek, A. J.; Jabłoński, M.; Palusiak, M. The nature of NO-bonding in N-oxide group. Phys. Chem. Chem. Phys. 2015, 17, 16375-16387.

(20) Balevicius, V.; Aidas, K.; Svoboda, I.; Fuess, H. Hydrogen bonding in pyridine $\mathrm{N}$-oxide/acid systems: proton transfer and fine details revealed by FTIR, NMR, and X-ray diffraction. J. Phys. Chem. A 2012, 116, 8753-8761.

(21) Hansch, C.; Leo, A.; Taft, R. W. A Survey of Hammett Substituent Constants and Resonance and Field Parameters. Chem. Rev. 1991, 91, 165-195.

(22) Bondi, A. van der Waals Volumes and Radii. J. Phys. Chem. 1964, $68,441-451$.

(23) Ullrich, R.; Dolge, C.; Kluge, M.; Hofrichter, M. Pyridine as novel substrate for regioselective oxygenation with aromatic peroxygenase from Agrocybe aegerita. FEBS Lett. 2008, 582, 4100-4106.

(24) Talele, T. T. Acetylene Group, Friend or Foe in Medicinal Chemistry. J. Med. Chem. 2020, 63, 5625-5663.

(25) Wilcken, R.; Zimmermann, M. O.; Lange, A.; Joerger, A. C.; Boeckler, F. M. Principles and applications of halogen bonding in medicinal chemistry and chemical biology. J. Med. Chem. 2013, 56, $1363-1388$.

(26) Wang, H.; Wang, W.; Jin, W. J. $\sigma$-Hole Bond vs $\pi$-Hole Bond: A Comparison Based on Halogen Bond. Chem. Rev. 2016, 116, 50725104.

(27) Cascini, G. L.; Niccoli Asabella, A.; Notaristefano, A.; Restuccia, A.; Ferrari, C.; Rubini, D.; Altini, C.; Rubini, G. 124 Iodine: a longer-life positron emitter isotope-new opportunities in molecular imaging. Biomed. Res. Int. 2014, 2014, 672094.

(28) Kuker, R.; Sztejnberg, M.; Gulec, S. I-124 Imaging and Dosimetry. Mol. Imaging. Radionucl. Ther. 2017, 26, 66-73.

(29) Wellendorph, P.; Høg, S.; Sabbatini, P.; Pedersen, M. H. F.; Martiny, L.; Knudsen, G. M.; Frølund, B.; Clausen, R. P.; BräunerOsborne, $\mathrm{H}$. Novel radioiodinated $\gamma$-hydroxybutyric acid analogues for radiolabeling and Photolinking of high-affinity $\gamma$-hydroxybutyric acid binding sites. J. Pharmacol. Exp. Ther. 2010, 335, 458-464.

\section{NOTE ADDED AFTER ASAP PUBLICATION}

This paper was published ASAP on October 8, 2021 with an error in the references. The error was corrected, and the revised paper reposted on October 11, 2021. 